\title{
Analysis on Application Scope of Mental Damage Compensation
}

\author{
Di $\mathrm{Wu}^{1, \mathrm{a}}$ \\ ${ }^{1}$ Oxbridge College, Kunming University of Science and Technology, Kunming, Yunnan Province, \\ China \\ a916952589@qq.com
}

Keywords: Mental Damage, Compensation System, Application Scope.

\begin{abstract}
Mental damage compensation belongs to civil damage compensation, and it is different from property damage compensation in several aspects. The essential elements for mental damage compensation are special. Victims are required to submit evidences besides their spiritual suffering. Now in China, there's not legal provision which stipulates the application scope of mental damage compensation. Thus in judicial practice, it is difficult for judges to determine whether the victims are allowed to receive compensation. In this paper, the application scope of mental damage compensation is discussed, in order to provide guidance on the specific work of judicial practice.
\end{abstract}

\section{Introduction}

The compensation system for mental damage has been controversial in China for a long time.[1] Some scholars believe that the system materializes humans' personality, and distorts values and morals, since it aims to punish the offender, and goes against the basic principles of the Civil Law. The author does not agree with this view. Mental damage refers to victim's painful feelings after mental attack. These sufferings cannot be relieved through direct compensation. Hence, victims need to receive compensations like realizing some kinds of rights or getting material and labor benefits to ease their pain. The system is consistent with the remedy function of Tort Liability Law, and does not go against the basic principles of the Civil Law. Therefore, the author believes that compensation system for mental damage should be advocated and implemented effectively.

\section{Analysis on Essential Elements of Mental Damage Compensation}

Tort Liability Law stipulates in the twenty-second article that, if a tort committed against the personal rights and interests of another results in serious emotional distress, the injured person may claim compensation for emotional distress. Though there's no clear regulation on essential elements for mental damage compensation, it can be inferred that mental damage is not the sufficient condition of obtaining compensation.

First of all, the source of victim's mental damage should be others' violation on his personal rights and interests. Through provisions of the Civil Law, we know that human rights are consisted of personality rights and status rights; specific contents include the right to life, right to health, right of portrait, right of reputation or honor, parental rights and so on. When the personal rights and interests of the victim are injured, the victim can request compensation for mental damage. If the general property rights of the victim are damaged, it is the property damage compensation system in Tort Liability Law that should be applied to the case, rather than the mental damage compensation system.

Secondly, only victims who suffer from serious mental damage can apply for mental compensation. In some cases, victims may illegally restrict offenders' behaviors, or try to make profit through their mental damage. In order to prevent these behaviors, Tort Liability Law makes specific regulations on the degree of mental damage. The Judicial Interpretation of Supreme People's Court on Liability for Mental Damage in Civil Tort also made provisions on the degree of compensation for mental damage. In the majority of tort cases, if the mental damages of victims are not serious, their request for compensation would not be supported by the court.

But the assessment standard of "serious mental damage" is still controversy. [2] Mental damage refers the victim's mental suffering caused by offender's behavior. It is a kind of subjective feeling, 
and cannot be measured objectively, or judged from external appearance. So it is difficult to be proved by the victim, or identified by the judge. Generally speaking, if the victim' s right to life, right to health or body right is injured to the point that it is disabled, the damage can be identified as "serious". In other cases, judges should make relatively strict judgment. If the spiritual personality rights of the victim (such as the right of reputation or honor) is damaged, Li-ming Wang believes that, the damage "must reach to a certain degree" to be identified as "serious". But there's still no detailed description on relative standards.

Finally, the requirement subject should be the victim. The mental damage compensation system aims to relieve victims' spiritual pain, rather than punish offenders. So only the victim of mental damage can apply for compensation. Victims' close relatives or other interested parties are not victims, and they cannot feel the pain of the victim. Thus, the legal system does not allow victims' close relatives or other interested parties to serve as requirement subjects.

\section{Specific Application of Mental Damage Compensation}

Damage of general personality rights. General personality rights mainly include the right of personality equality, freedom, independence and dignity. The right of personality equality means that, all citizens enjoy equal personality rights, regardless of their class, nationality, race or property. The right of personality freedom means that, everyone enjoys freedom to think, speech and act within the scope provided by the law, or within the scope which is not prohibited by the law. No person or organization shall interfere. As the basic right of citizens, the right of personality independence is stipulated in the Constitution. Each person is an independent individual. No person or organization could ignore this feature and infringe upon the legitimate rights and interests of others. Respect for dignity is the innate requirement of human beings, and should be supported by all citizens. The law cannot be strong enough to protect the country, unless it can protect citizens' rights of personality equality, freedom, independence and dignity, as well as other rights and interests. General personality rights damage is the injury to the basic rights of the victim, and is bound to victim's mental suffer. If the mental damage is serious, victims can apply for compensation.

Damage of specific personality rights. Specific personality rights are quite vulnerable under tortious behaviors. [3] Citizens' rights to life, health, reputation, honor, portrait, name and body are belong to specific personality rights. These contents in specific personality rights are carriers of citizens' spiritual ballast. Without healthy bodies and honor awards, citizens are unable to get spiritual pleasure and satisfaction. If citizens' specific personality rights and interests are infringed by others, their spiritual pleasure and satisfaction will be injured, and corresponding spiritual distress will occur. If the mental damage is serious, victims can apply for compensation.

Damage of status rights. The Tort Liability Law stipulates that, if a tort committed against the personal rights and interests of another results in serious emotional distress, the injured person may claim compensation for emotional distress. [4] In addition to the rights of personality (including general personality rights and specific personality rights), citizens also enjoy the rights of status. The rights of status are based on citizen's marriage or family status. Generally speaking, the rights of status include parental right, right of kinship, spouse right and others. Parental right refers to parent's right and obligation on educating and protecting their under age children. Right of kinship refers to the right of identity between parents and adult children, grandparents and grandchildren, as well as brothers and sisters. Spouse right is citizen's right to ask for companionship, love and assistant from his or her spouse. These rights are citizens' spiritual requirements on the basis of their marriage and family. If these needs are violated, citizens' emotional needs cannot be met, and mental suffer may occur. Therefore, if some specific status rights are violated, victims can apply for compensation.

Damage of personality rights of the dead. The right of personality is a kind of natural right of human beings. People are born with these natural rights, and they do not need to obtain them through other kinds of actions or legal behaviors. The dead cannot enjoy personality interests. But the Judicial Interpretation of Supreme People's Court on Liability for Mental Damage in Civil Tort issued in March 10, 2001 stipulates that, although the civil rights of the dead are eliminated, some personality rights of them are still being protected by the law. The protection on their names, portraits, 
reputations, honors, privacies and bodies will not disappear because of their death. If someone injure their rights of personality, though the dead cannot feel the pain, their close relatives who have spiritual connection with them may suffer from mental damage. In these cases, close relatives of the dead are allowed to apply for damage compensation in the name of personality right damage of the dead.

Damage of specific souvenirs with symbolic meaning on personality rights. In our country, the application of compensation for mental damage is the damage to citizens' personality rights and interests. Hence, compensation for mental damage seems not applicable in property damage cases. Generally speaking, property damage cases which only involves with the loss of property do not relate to spiritual damage. According to the function of remedy damage of the Tort Liability Law, the corresponding amount of property compensation should be paid to victims, while mental compensation is not necessary. However, if the damaged property has special commemorative significance, the nature of the property will be changed.[5] These articles are unique to victims; victims regard these things as their spiritual sustenance. The damage of these items will hurt victims' inner feelings, and may produce painful memories to the victim. If the victim cannot apply for mental compensation under that circumstance, the original intention of mental damage compensation system will be violated. Therefore, mental damage compensation method should be applied to the damage of specific souvenirs with symbolic meaning.

\section{Mental Damage Compensation under Special Circumstances}

Can legal persons serves as subjects of mental damage compensation? The subject of mental damage compensation refers to the victim with mental suffering caused by damage on personality rights or interests. The spiritual losses of victims have affected their normal life and work. Natural persons can serve as the subjects of compensation, since they have normal emotional expressions and spiritual perceptions, and the injury on their personal interests can lead to their mental damage. The term of legal person refers to a kind of collective organization. A legal person can enjoy some personality rights, such as the right of name and reputation. If legal persons' personality rights are damaged, can they apply for mental damage compensation? The question is still debated in theoretical and judicial circles.

Some scholars believe that, [6] a legal person is consisted of natural persons. The damage to its interests will inevitably affect the mental statues of natural persons. The mental depression and mistakes of natural persons, or staffs, will affect the normal operation of the legal person, and may lead to great losses. Thus, regulations should protect the personality rights of legal persons, and allow them to serve as the subjects of mental damage compensation.

The author does not agree with the above point of view. Judicial Interpretation of Supreme People's Court on Liability for Mental Damage in Civil Tort stipulates in the fifth article that, if the legal persons or other organizations apply for mental damage compensation for their injuries on personality rights, the court will not approve. It can be seen that Chinese laws do not recognize legal persons' rights of receiving mental damage compensation. The natural persons may suffer mental distress due to the reduction on the external evaluation of the legal person, but the distress can not affect their normal life and work. In other words, natural persons do not suffer serious mental damage. The legal person does not have physical perceptions or emotional expressions, so mental damage cannot happen to them. Professor Xin-bao Zhang also believes that, "legal persons have some kinds of personality rights, but they do not have psychological or mental feelings. Certainly, they would not suffer mental damage". Therefore, legal persons cannot serve as subjects of mental damage compensation.

Can fetuses serve as subjects of mental damage compensation? The Civil Law of our country clearly stipulates that, the rights of citizens begin at their birth and end in their death. Citizens are not entitled to civil rights before birth, and they do not enjoy the right to claim compensation. Among current laws and regulations, only the Inheritance Law stipulates that, the expectant right of fetus should be retained. There's no relevant regulation on fetus' right to claim mental damage 
compensation. It seems that this kind of compensation is not proper. The author holds opinions on this issue.

It is true that the rights of citizens begin at their birth and end in their death. The fetuses are not born, and therefore they do not enjoy civil rights. However, the application scope of the mental damage compensation in the Tort Liability Law is the damage to citizens' personality rights and interests, rather than their civil rights. The rights of citizens end in their death, but the law of our country still protect some personality interests. Therefore, even if the dead are gone, some of their civil rights and interests are still protected by law. So as to the fetus not born. If the fetus exists in the womb of a woman, its civil rights and interests should be retained. If someone's behaviors injure it's rights, and will affect its normal life and work in the future, the guardian of the fetus should be allowed to apply for mental damage compensation as the legal agent. For example, [7] a expectant mother goes to a hospital, and get infected with HIV virus during transfusion because of the negligence of doctors and nurses. Under that condition, the fetus will be infected with HIV, and after birth, the virus will be carried by the person during the whole life. It will seriously affect the victim's future life and work. If the fetus' rights of applying for mental damage compensation cannot be guaranteed, the law will be unfair to it. Therefore, in my opinion, the compensation system for mental damage should learn from the Inheritance Law, and allow fetuses serve as subjects of mental damage compensation, in order to protect their legitimate rights and interests.

\section{References}

[1] Y.L. Han, L.J. Lu, On basic issues of mental damage compensation, J. Journal of Shaanxi Institute of Junior Managerial Personnel. 2 (2012)

[2] D.H. Tang, Interpretation and Application of Judicial Interpretation on Liability for Mental Damage in Civil Tort, People's Court Press, Beijing, 2015.

[3] X.B. Zhang, Research on Mental Damage Compensation System, Law Press - China, Beijing, 2012.

[4] Y.M. Liu, Compensation for Mental Damage, China Democracy and Legal System Publishing House, Beijing, 2014.

[5] H.X. Liang, Interpretation on Tort Liability Law of China, J. Northern Legal Science. 1 (2011).

[6] H. Sun, Research on the legal issues of mental damage compensation, Ocean University of China, 2013.

[7] K. Qian, Research on compensation for mental damage in civil tort, J. Journal of Nanyakn Institute of Technology. 1 (2014). 